$\begin{array}{ll}\text { Titel: } & \text { Ons kom van ver. Naledi } \\ \text { Outeurs: } & \text { Carstens, W.A.M. en M. le Cordeur. } 2016 \text { (Redakteurs) } \\ \text { Bladsye: } & \text { 599pp }\end{array}$

\title{
Oor mense, afstande en Afrikaans
}

In 2016 het Wannie Carstens en Michael le Cordeur'n betekenisvolle bundel van 36 verhale, Ons kom van vêr, saamgestel. Hulle het Afrikaanssprekendes wat Afrikaans oorwegend as 'n variëteit buite Hoofstroomafrikaans beleef het, vir vertellings gevra oor 'n insident uit hulle lewens waarby Afrikaans ter sprake was (vgl.: xvi). Die stories van "hierdie groep sprekers van Afrikaans" (Le Cordeur: xvi) handel oor verskeie gebeurtenisse, waarvan die subteks Afrikaanssprekendes se verset teen apartheid was, veral tydens die 1980's tot in die middel van die 1990's. Dié gebeurtenisse is 'n onweglaatbare deel van die tans nog ongeskrewe geïntegreerde geskiedenis van die Afrikaanssprekende mense van Suider-Afrika.

"My moedertaal is ook op Vryheidsdag in 1994 bevry", het Patrick Mettler ervaar (p. 141). Sy verhaal, en die meeste ander verhale van Ons kom van vêr, gaan oor gebeure uit die tweede helfte van die twintigste eeu, maar die mense van lank gelede, die "eerste nasies" (Le Cordeur, p. xviii; Boesak, pp. 112-128), se ou-ou erflatings en strewes na selfverwesenliking is ook ingesluit. Hulle het ook 'n aandeel aan dié verhale, en leef van vroeg af met 'n "geankerdheid aan hierdie land" (Titus, p. 187). Afrikaans en sy baie kante kom inderdaad van vêr.

Hierdie bundel is by verre nie 'n griefskrif nie. Die meeste van die vertellings boei, en baie is met 'n aansteeklike geesdrif geskryf. Insidente en feite en vertellings vleg deureen, en lig dokumentêr nuwe aksente uit. Hoeveel mense is daar nie wat in daardie jare aan die struggle deelgeneem het nie? Mense wat hulle belangrike aandeel in die stryd teen apartheid daarna vir ander rolle verruil het. Die boek is vol name van gemeenskapsleiers, predikante, burgemeesters, politici en akademici, asook van voetsoolaktiviste wat 'n bevryde Afrikaans in die oog gehad het (vgl. p. 233): ’n Ererol. Mettler voer aan dat dáárdie doelwitte nog nie bevredigend bereik is nie (pp. 129-149).

Soms verwys skrywers in die verbygaan na die greep van apartheid op hulle lewens, ander kere staan die verhaal van verset en bevryding meer prominent.

Fatima Allie (pp. 506-520) gee nie die status aan die apartheidspraktyk wat 'n direkte frontaanval sou doen nie. Met grepe van haar Afrikaans deel sy in haar vertelling die geur en die smake en kleure van Maleise kos met lesers. Om self sulke kos te maak "moet [jy] versieker da rit reg smaak en darie kleur reg is"(p. 509). Soos die kos, kom haar voorsate ook van vêr af, uit Indonesië en Maleisië. Een van Fatima Allie se voorvaders was die vooraanstaande Kaapse Imam, Tuan Guru ("meneer die onderwyser") wat die tradisie van geskrewe Kaapse Afrikaans en geletterdheid aan die einde van die agtiende eeu in die Dorpstraat Madrassa begin het. Op 'n nostalgiese noot herinner sy haar nog aan die lekkers wat Achmat Davids, die bekende kenner van Kaapse Moesliemafrikaans, "vir ons kinners ... gegie het" (p. 510).

Sy vertel terloops dat dit maklik is om haar geboortedag te onthou. Dit was die dag toe Distrik Ses vir haar'n verbode gebied geword het. Inwoners is toe kragtens die onverdedigbare Wet op Groepsgebiede van 1950 (Wet No. 41 van 1950), uit hulle woonhuise gesit, en mense is van hulle geboorte af lewenslank gemerk. Verdedigbaar? Die vraag is aanhoudend gevra. 
Ook nadat die Nederduitse Gereformeerde Kerk besluit het om in 1881 'n afsonderlike kerk in die lewe te roep (p. 43), die Nederduitse Gereformeerde Sendingkerk (NGSK), ondergeskik aan die moederkerk, waaroor Llewellyn MacMaster (pp. 237-256) skryf. Dit was nie op teologiese gronde verdedigbaar nie, wys Mary-Anne Plaatjies-Van Huffel (p. 73) uit.

Gavin Davis (pp. 272-283) se vertelling volg in die trant van Fatima Allie s'n. Hy koester die elegansie van die langarm-kapityt danskultuur met geesdrif, en deel met die leser iets van die eie aard hiervan soos dit op die Kaapse Vlakte en daarbuite ervaar word, waar kappityt'n tipiese langarmdanswoord is (p. 275). Hy verskaf verbasende besonderhede oor orkeste met hulle treffende name, en waardeer die radio-erkenning daarvan. Is daar 'n insinking in die uitleef van langarm in dié musiekwêreld, wonder hy? Hy het daarmee grootgeword, in Willowdene en in die Baai. En dan noem hy, so half in die verbygaan, wat besondere trefkrag aan sy mededeling gee, dat daar "vandag net'n bos is nadat die mense van sy grootwordwêreld daar verwyder is" (p. 275). Óók kragtens daardie Groepsgebiedewet.

Christo van der Rheede wys vroeg in Ons kom van vêr op die gevolge van die ingreep wat op rasseskeiding gegrond was (p. 22), op die normale sosio-maatskaplike patrone van gemeenskappe in Suid-Afrika. Dit het 'n groot deel van die Afrikaanse gemeenskap met "opgekropte emosies, bitterheid en uitsigloosheid" gelaat (p. 23). In sy stimulerende bydrae wys Reggie Nel (pp. 57-71) hoe daardie ingrepe by "die rol van die opkoms van rasteorieë in die 18de en 19de eeu" invoeg (p. 64).

'n Illustrasie van die gevolge van hierdie ingrepe op normale sosio-maatskaplike gedrag? Patrick Mettler (pp. 129-145) en Charles P. Beukes (pp. 327-352) illustreer dit met binneanekdotes wat hulle met die lesers deel uit'n tyd toe sport die politieke voetangels van daardie tyd nie kon systap nie, en vertel ook van presteerders se individuele prestasies. Odessa (Krause) Swarts "was waarskynlik die mees begaafde vroue-naelloopkampioen van SACOS in die 1980's" (p. 339). Hoe sou sy nie gevaar het in die wêreld daarbuite wat vir haar gewink het nie? Haar man was 'n hoogspringer. Hulle seun, Wayde van Niekerk, is tans die 400 meter wêreldrekordhouer. Onafhanklik van mekaar roep hierdie skrywers die tennisster David Samaai se prestasies in herinnering: hy het drie keer op Wimbledon deelgeneem, maar kon nie tuis teen die Suid-Afrikaanse kampioen kragte meet nie (p. 134). Hulle wys op nog baie ander gevalle. Hoe verdeel 'n ambisieuse jong koerantman hom in twee of meer? Hy moes maar! Van dié rondhardlopery vertel Beukes ook (p. 331).

Onder die oppervlaktes van die verhale in Ons kom van vêr lê daar nóg verhale. Willa Boesak (p. 128) vertel nie net van die bekoorlike eiesoortigheid van binnelandse Afrikaans, en van die N/u en die $\$$ Khomani San (p. 117), en van die pleknaamerflatings van die sprekers van Khoi-Afrikaans (pp. 112-115) nie. Hy vertel ook 'n verhaal van soeke na identiteit (o.a. p. 144). Dit is ook die geval met Elias P. Nel (p. 318-326) se bydrae oor die ontwikkeling van die kulturele erfenis van die Khoi en San (p. 319). Reggie Nel (p. 61 e.v.) vou sy verhaal om die gevolge van die Kapenaars se deelname aan "die ekonomiese belange van die VOC" wat ook vra na 'n hedendaagse perspektief op gebeurtenisse van vêr terug.

Die verhale is vol besondere wetenswaardighede. Marlene le Roux vertel (pp. 284-298) van die rol van Afrikaans in opbouende jeugprogramme om sosiale transformasie te fasiliteer. Henry Jeffreys (pp. 354-363) se vertelling gaan oor sy rol in 'n media-binnekamer (Die Burger), in die stoel van D F Malan, en hy maak die uitspraak "dat Afrikaans ons almal sal oorleef". As gewese redakteur het hy ander ervarings gehad as Conrad Sidego (pp. 380-392) wat uit'n vroeër periode as Redakteur van Ekstra-Burger vermaaklik vertel hoe hy "soos 'n koejawel in 'n piesangboom" (p. 381) die koerantopset van daardie tyd ervaar het.

Die reaksie op die tweede deel van die versoek aan die skrywers, dat Afrikaans by die 
vertellings betrek word, lig belangrike gegewens uit oor taalhoudings, persepsies en taalfunksies, en oor Afrikaans se gebruik in verskillende omgewings. Die vertellers se ervarings van Afrikaans illustreer die uitgangspunt dat tale se geskiedenis in der waarheid om die lotgevalle van sprekers wentel. Al die sprekers van Afrikaans het aan die maak van sy geskiedenis deel gehad en hulle taal bewaar die getuienis van hulle lotgevalle, oor baie geslagte heen.

Dialekte verkeer in die reël onder druk van die standaardkode, omdat onderwys- en ander normerende funksies daarin uitgevoer word. Met die dialekte van Afrikaans is dit anders gesteld. Dialekafrikaans se lewe is verleng omdat dié taalvorm as protessimbool teenoor Standaardafrikaans gefunksioneer het. Adam Small, aan wie hierdie boek opgedra is, se werk in Dialekafrikaans het daartoe bygedra (vgl. Nico Koopman, pp. 539-551 daaroor), soos die Dialekafrikaans van ander skrywers en digters ook. Variëteite waarin hoër funksies beoefen word, kan nie sommer tersyde gestel word nie, toon Danny Titus (pp. 200-201) aan. Nie een van Afrikaans se variëteite kan in elk geval as die toonaangewende Afrikaanse taalvorm beskou word nie. 'n Dialek kan nie die gestandaardiseerde spel- en skryfkode se rol oorneem nie, dialekte is tale wat anders funksioneer as die standaardkode.

Die Afrikaans van die verhale? Meermale kom die leser verfrissende uitlopers van Dialekafrikaans teen, en gedagtes daaroor. John D. Diergaardt vertel hoe nasieners (vgl. pp. 394-40) juis oor antwoorde in Dialekafrikaans kop gekrap het. Meermale gebeur dit dat Afrikaans nie net die taal van die vertelling is nie, maar ook die objek van die vertelling: die taal van die struggle was ook die taal van Apartheid: die lem van Afrikaans is aan al twee kante geslyp, waarop Franklin Sonn ook wys (agterblad). Die afdwing van verskillende leefwêrelde het verskillende taalervarings meegebring, kom die leser gou agter, in 'n SuidAfrika waar "heterogene Afrikaans" (Titus, p. 83 e. v.) buitendien, al is dit om ander redes, 'n werklikheid is.

Die warmte van die vertelling van Le Cordeur (pp. 258-271) oor die Kaapse en Wellingsonse Klopse, en hulle lang tradisie, is 'n heerlike leeservaring. Hy verf die klopsefamilie se mengeling van kleure op hulle groot dag meevoerend in sy storie in, noem 'n rits treffende name, vertel van die verhale daaragter, en wys ook op die ironie wat in die groepnaam millionaires skuil. Wat is 'n moppie, en wie ken die storie van die Alibama? Daaroor, en oor nog baie meer, skryf hy. Hoekom Klopse? Vir niks anders nie as "net virrie liefde daarvan" (p. 270).

Openbare gedagtewisseling was een van die maniere om verset teen apartheid te stimuleer en te koördineer. In 'n tyd toe sulke diskoerse nie moontlik was nie, is ander planne beraam. Le Cordeur (pp. 299-317) vertel van die plegtige openings van die krisanteskou op Wellington. Van 1966 af, na die eerste 50 jaar van die bestaan van dié vereniging, lui die storie agter die storie, het die belangrike genooide sprekers hulle toespraakgeleenthede gebruik om kritiese kommentaar op die politieke situasie te lewer, en het sodoende "'n gemeenskap wat grotendeels uitgesluit was van die politieke debat in die media"'n kans gegee om ook'n "sê te sê" (p. 304). Dié gemeenskap het 'n naarstiglike behoefte aan gespreksgeleenthede oor die onbegryplike diskriminasie teenoor hulle gehad. Vir Basil Kivedo (pp. 476-488) was dit al vervullend om net te kon hoor "hoe die mense van die [Christelike Instituut van Beyers Naudé] teen apartheid" praat (p. 478). Later was daar sprake van direkte verteenwoordiging in plaaslike regering, en kon politieke gesprekke ongehinderd plaasvind, herinner Herman Bailey hom. In die Boland was Afrikaans daardie gesprekstaal (p. 458-475).

Die Universiteit van Wes Kaapland (UWK) het ook 'n platform geskep om op 'n intellektuele vlak in Afrikaans vorm te gee aan verset. Individue het hulle rewolusionêre insigte gedeel, in Afrikaans, en as 'n groep het die teologiestudente hulle stempel op gesprekke afgedruk (Beukes, p. 45). Dié gedagtes is omgesit in daadwerklike optredes, waaroor Llewellyn 
MacMaster (p. 243 e.v.) informatief skryf (en die akroniem UWC interessant uitlê!). Kampusse, ook van onderwyskolleges, is gou "beskou as 'sites of struggle"' (p. 417), skryf Basil May in sy vermeldenswaardige bydrae (p. 410-426). En op skoolvlak? Danie van Wyk (pp. 427-443) onthou hoe individue in gemeenskappe van vêr af uitgereik het om skoolkinders te huisves wat slegs na die skole toe kon gaan wat vir hulle aangewys is.

Op'n ander vlak was die Belydenis van Belhar ook'n manier om teen apartheid te protesteer. Dit is in Afrikaans gekonsipieer, "twee jaar na die 1976-opstand", beklemtoon Jaques Beukes (p. 39) die simboliese betekenis van die Soweto-opstand. In dié belydenis was "die invloed van ... Afrikaanssprekende Christene deurslaggewend in die bevryding van die land se mense", skryf hy met trots (Beukes p. 43). Mary-Anne Plaatjies-Van Huffel verwys na die N G-Kerk "se stilswye teen die onregverdige apartheidsbestel" (p. 104) wat deels die aanloop vir dié belydenis verskaf het, en wat aansluit by Beukes (p. 44) se vertelling oor ds. Isak Morkel, ’n "profiet" wat nie in sy eie land geëer is nie, en wat nie "liefde kon preek en apartheid in praktyk ... beoefen nie". Dit het op sy stigting van die Calvyn Protestantse Kerk uitgeloop.'n Geskiedenis wat Raymond van Diemel (pp. 93-110) met passie dokumenteer.

Dié Soweto-onluste van 1976 het simboliese waarde gekry in die struggle-tyd, en het dit daarna behou. Edwena Goff (pp. 205-219), soos ander skrywers ook, gebruik dié onluste as 'n verwysingspunt in haar verhaal: "(e)k was in die middel van standerd 9 (graad 11) toe die 1976-Soweto-opstand" plaasgevind het, onthou sy (p. 208). Michael le Cordeur (pp. 220-236) deel waardevolle herinneringe oor "daardie grou wintersdag, 16 Junie 1976", en noem dat daardie opstand "meer kompleks is as wat dikwels uitgebeeld word" (p. 234). Hy wys op die rol van Steve Biko se Swartbewussynsbeweging daarin (pp. 230-232), soos Llewellyn MacMaster (pp. 237-256) ook. Daarna het die land begin brand, en is lewens in die Wes-Kaap uitmekaar geruk. Die kreet "hek toe" het aan UWK opgeklink as gevaar gedreig het. Basil Kivedo, 'n gewese MK-soldaat, herinner hom aan die vergaderings wat as "ghoemas", "langarmdanse" of "brieksies" bekend gestaan het (p. 482), en waar Afrikaans die vergaderingstaal was, ondanks die etiket van "die taal van die verdrukker" (p. 233). Llewellyn MacMaster (pp. 237-256) vertel ook van die herlewing van die bevrydingstryd, van 1968 af, en wys interessant op die "sukses van bevrydingsbewegings teen Portugese kolonialisme in Angola en Mosambiek" (p. 240) wat as aansporing daarvoor kon gedien het.

Afrikaans kom op 'n ongewone pad saam met die bydraers van Ons kom van vêr, en met hulle voorsate. Dit is 'n gekoesterde moedertaal met die baie gesigte van baie variëteite (vgl. Patrick Mettler, pp. 129, 143). Aan Afrikaans se vestiging "as skryftaal van die Afrikaanssprekendes" (Van Huffel, p. 76) in die plek van Nederlands, het die lidmate van die Nederduitse Gereformeerde Sendingkerk (NGSK) tussen 1910 en 1920 aktief meegewerk. Afrikaans het sy vroeëre funksies egter nie deurgaans daar behou nie. Nadat die Verenigde Gereformeerde Kerk van Suid-Afrika (VGKSA) in 1994 gestig is, het die Algemene Sinode in 1997 op grond van sy "multikulturele en multitalige agtergrond" besluit om Engels op sinodevlak te gebruik (Van Huffel, p.89).

Dialeksprekers kan die Standaardkode van Afrikaans in 'n diglossiesituasie gemaklik naas Dialekafrikaans beheers. Basil Kivedo vertel hoe hy vir sy teenstand teen apartheid gearresteer is, en hoe die landdros tydens sy verhoor by tye oopmond sit en luister het na die keurige Afrikaans waarin hy sy verdediging waargeneem het (p. 478). In 'n politiekgelaaide dialekomgewing het Standaardafrikaans soms 'n stigma gedra, en is Standaardsprekers geëtiketteer as "'n boejong" (boerejong), onthou Edwena Goff (p. 212).

Die oorkoepelende narratief oor Afrikaans en sy mense het baie kante en het baie vertellers. Die verhale in Ons kom van vêr vorm boublokke van belangrike momente vir'n oorkoepelende 
geskiedenis van Afrikaans. Om dit na behore te ontgin, het die boek 'n indeks nodig, wat ongelukkig ontbreek. Die bundel gee ook nie blyke van "die ontwikkeling van Afrikaans" soos wat die subtitel te kenne gee nie. Die samestellers moet krediet kry vir die netjiese ordening van die bydraes, en vir die talle foto's wat ingesluit is, selfs kleurfoto's, wat van Ons kom van vêr'n kosbare besitting maak.

Hierdie werk is 'n besondere welkome bydrae wat vêr in meer as een betekenis uitlig. By die redakteurs van Ons kom van vêr se oorspronklike versoek om bydraes, kan lesers byvoeg: sodat Afrikaanssprekendes meer van mekaar af kan weet ...

Die verhale van Ons kom van vêr bly die leser nog lank by. Moes hierdie boek nie al lankal verskyn het nie?

\section{Christo van Rensburg}

Navorsingsgenoot: Navorsingseenheid Tale en literatuur in die SA konteks,

Noordwes-Universiteit,

Potchefstroom-Kampus

Christovanrensburg100@gmail.com 